\title{
AMENDMENTS
}

\section{Author Correction: Structural basis for polyglutamate chain initiation and elongation by TTLL family enzymes}

Kishore K. Mahalingan, E. Keith Keenan, Madeleine Strickland (D), Yan Li (D), Yanjie Liu, Haydn L. Ball, Martin E. Tanner (D), Nico Tjandra (D) and Antonina Roll-Mecak (D)

Correction to: Nature Structural \& Molecular Biology https://doi.org/10.1038/s41594-020-0462-0, published online 3 August 2020. In the version of this article initially published online, author E. Keith Keenan's surname was incorrect. The error has been corrected in the print, PDF and HTML versions of the article.

Published online: 13 August 2020

https://doi.org/10.1038/s41594-020-0498-1

This is a U.S. government work and not under copyright protection in the U.S.; foreign copyright protection may apply 2020

\section{Publisher Correction: Scaling up dissection of functional RNA elements}

Marc Bühler (iD) and Alex Charles Tuck (DD)

Correction to: Nature Structural \& Molecular Biology https://doi.org/10.1038/s41594-020-0482-9, published online 3 August 2020.

In the version of this article initially published online, reference 1 was incorrect; the correct reference is: Jia et al. Nat. Struct. Mol. Biol. https://doi.org/10.1038/s41594-020-0465-x (2020). The error has been corrected in the print, PDF and HTML versions of the article.

Published online: 12 August 2020

https://doi.org/10.1038/s41594-020-0491-8

๑ Springer Nature America, Inc. 2020 